\title{
PERAN IBU YANG BEKERJA DALAM PEMENUHAN KEBUTUHAN DASAR ANAK
}

\author{
Oleh: \\ Fitriyani, Nunung Nurwati, \& Sahadi Humaedi \\ Email:
}

fitriyanivvt@gmail.com

\begin{abstract}
Abstrak
Di zaman yang serba modern ini banyak perempuan yang memilih bekerja atau menjadi wanita karier dibandingkan dengan menjadi ibu rumah tangga biasa. Hal ini bukan tanpa alasan melainkan semakin banyaknya kebutuhan hidup yang harus dipenuhi. Meskipun telah ada suami yang bertugas untuk mencari nafkah agar terpenuhinya kebutuhan hidup namun karna sekarang harga-harga semakin mahal terkadang penghasilan suami tidak cukup untuk memenuhi kebutuhan-kebutuhan tersebut. Maka dari itu istri bekerja membantu suami agar kebutuhan hidup dapat terpenuhi sehingga dapat bertahan hidup. Namun di sisi lain pada hakikatnya peran seorang istri adalah mengurus rumah tangga termasuk mengurus anak. Bagaimana seorang anak mendapatkan kasih sayang, bagaimana seorang anak mendapatkan pendidikan dan lain lain, hal itu merupakan tugas seorang istri yang sekaligus berperan sebagai ibu. Hal ini terkadang menjadi sebuah dilema bagi seorang istri, di sisi lain ia ingin memberikan yang terbaik untuk anaknya agar mendapatkan kasih sayang, pendidikan, asupan makanan dan nutrisi yang tepat, namun di sisi lain ia juga ingin bekerja membantu suaminya agar dapat membantu menambah penghasilkan agar terpenuhinya kebutuhan hidup. Hal ini menjadikan seorang ibu harus berperan secara ganda yaitu sebagai seseorang yang membantu mencari nafkah membantu suaminya dan menjadi seorang ibu yang utuh yang bertugas mengasuh anak dalam memenuhi setiap kebutuhan anaknya.
\end{abstract}

Metode yang digunakan dalam penelitian ini adalah metode penelitian kualitatif. Dengan menggunakan metode kualitatif peneliti dapat mendeskripsikan bagaimana peran ibu yang bekerja dalam pemenuhan kebutuhan dasar anak. Selain itu peneliti juga menggunakan metode deskriptif agar dapat menggambarkan secara lengkap dan mendalam bagaimana peran ibu yang bekerja dalam memenuhi kebutuhan dasar anaknya.

Kata kunci: perempuan yang bekerja, kebutuhan dasar anak

\section{Abstact}

In this modern age many women who choose to work or be a career woman than being a housewife. It is not without reason, but the increasing number of needs that must be met. Thus the husband and wife work in order to help the living needs can be met in order to survive. But on the other hand is essentially the role of a wife is taking care of the household, including care of the child. How does a child get love, how does a child get an education, and others, it is the duty of a wife who once served as the capital. This sometimes becomes a dilemma for a wife, on the other hand he wants to give the best for their children to get affection, education, food intake and proper nutrition, but on the other hand he also wants to work to help her husband in order to help increase money order fulfillment of life. It makes a mother must be a double role, namely as someone who helped make a living helping her husband and becoming a mother is intact in charge of caring for the child to meet his every need. 
The method used in this research is qualitative research methods. By using qualitative methods researchers can describe how the role of working mothers in the fulfillment of the basic needs of children.

Keyword: basic needs children, working women

\section{PENDAHULUAN}

Di era globalisasi yang semakin maju ini dalam memenuhi kebutuhan hidup bukan hanya kebutuhan primer saja yang harus dipenuhi, bahkan kebutuhan sekunder dan tersier pun sekarang sudah menjadi kebutuhan hidup utama yang harus dipenuhi. Harga kebutuhan hidup tersebut semakin hari semakin mahal harganya, sehingga hal tersebut membuat kita harus semakin giat dalam mencari uang untuk memenuhi kebutuhan hidup tersebut. Untuk memenuhi kebutuhan hidup tersebut terutama kebutuhan keluarga saat ini tidak sedikit istri yang bekerja untuk membantu suaminya mencari nafkah untuk membantu perekonomian keluarga. Zaman dahulu seorang istri hanya bertugas sebagai ibu rumah tangga, namun pada zaman yang modern ini dengan adanya emansipasi wanita dan kesetaraan gender maka mindset tersebut telah berubah bahwa seorang istri pun berhak untuk bekerja seperti layaknya seorang suami. Maka dari itu bisa saja dalam satu keluarga suami dan istri keduanya bekerja untuk memenuhi kebutuhan hidup.

Keinginan seorang istri untuk bekerja dapat mempengaruhi peran dan status dalam keluarga. Kewajiban dari seorang istri salah satunya adalah mengurus anak. Apabila seorang istri bekerja maka ia harus membagi waktu antara perannya sebagai wanita karier dan sebagai ibu. Dalam perkembangan seorang anak, peran ibu menjadi sangat penting. Apabila seorang anak tidak mendapatkan peran ibu ketika proses berkembang maka dalam pemenuhan kebutuhan dasarnya akan terhambat.

Ada tiga kebutuhan dasar yang harus dipenuhi agar anak mengalami proses tumbuh kembang yang optimal, yaitu:
1. Kebutuhan fisik dapat dipenuhi apabila anak mengkonsumsi makanan sesuai dengan kebutuhan umurnya, pemantauan tumbuh kembang, pemeriksaan kesehatan, pengobatan, rehabilitasi, imunisasi, pakaian, pemukiman yang sehat dan lain-lain.

2. Kebutuhan emosinal meliputi segala hubungan yang erat, hangat dan menimbulkan rasa aman serta percaya diri sebagai dasar bagi perkembangan selanjutnya.

3. Kebutuhan stimulasi atau pendidikan meliputi segala aktivitas yang dilakukan mempengaruhi proses berpikir, berbahasa, sosialisasi dan kemandirian seorang anak (Hurlock, 1978:257)

Tidak terpenuhinya kebutuhan dasar dari seorang anak karena kurangnya interaksi dan perhatian dari orang tua terutama ibu yang berperan sebagai pengasuh dan pendidik anak. Selain itu hal yang akan terjadi apabila tidak terpenuhi kebutuhan dasar adalah anak akan menjadi terlantar.

Metode penelitian

Metode pada dasarnya merupakan cara yang digunakan untuk mencapai tujuan. Metode yang digunakan pada penelitian ini adalah metode kualitatif. Penggunaan metode kualitatif dipilih oleh peneliti untuk memahami suatu permasalahan mengenai peran ibu yang bekerja terhadap pemenuhan kebutuhan dasar anak . Pada metode ini peneliti mendeskripsiakan permasalahan dengan menggunakan kata-kata. Oleh karena itu, metode kualitatif lebih sesuai karena penelitian ini tidak memungkinkan untuk diukur secara tepat dengan menggunakan angka. 
Selain itu penelitian ini menggunakan metode deskriptif. Peneliti menggunakan metode ini dengan alasan agar dapat menggambarkan secara lengkap dan lebih mendalam bagaimana ibu yang bekerja dalam memenuhi kebutuhan dasar anak. Dengan menggunakan metode deskriptif, peneliti akan lebih mudah untuk mengemukakan gejala atau permasalahan peran ibu yang bekerja dalam memenuhi kebutuhan dasar anak secara lengkap, agar lebih jelas keadaan dan kondisinya.

Agar seorang anak dapat tumbuh dan berkembang dengan optimal maka seorang ibu harus memenuhi kebutuhan dasar tersebut. Seorang ibu yang bekerja artinya harus melakukan peran ganda yaitu sebagai seorang perempuan yang bekerja membantu menambah penghasilan suami dan sebagai seorang ibu yang bertanggung jawab atas anaknya, dengan demikian penelitian ini akan menjelaskan bagaimana peran ibu yang bekerja dalam memenuhi kebutuhan dasar anak.

\section{TELAAH PUSTAKA}

Perempuan yang bekerja

Perdebatan tentang permasalahan perempuan yang bekerja menurut SC.Utami Munandar dalam penelitian Fungsi Keluarga untuk meningkatkan sumber daya manusia di wilayah Riau (Depdikbud:2000) tidak perlu lagi, karena menurutnya banyak hal positif dari wanita bekerja yaitu:

1. Bekerjanya istri atau ibu mempunyai dampak positif terhadap rasa harga dirinya dan sikap terhadap diri sendiri

2. Ia lebih merasa puas hidupnya juga membuat dirinya lebih mempunyai pandangan positif terhadap masyarakat.

3. Istri atau Ibu yang bekerja lebih sedikit menunjukan keluhan fisik, dengan perkataan lain kesehatan mereka tidak terpengaruh secara negative oleh tuntutan-tuntutan dari rumah maupun pekerjaan.
4. Dalam mendidik anak, ibu-ibu yang bekerja kurang menggunakan teknik disiplin yang keras atau otoriter. Mereka menunjukan lebih banyak pengertian dalam keluarga.

5. Pada umumnya istri atau ibu yang bekerja lebih memperhatikan dan merawat penampilan

6. Dengan bekerja kewaspadaan mental menjadi lebih berkembang

7. Mereka dapat menunujukan lebih banyak pengertian terhadap pekerjaan suaminya dan masalah-masalah yang bersangkutan, sehingga mempunyai dampak positif terhadap hubungan suami istri

8. Pada umumnya Istri atau ibu yang mempunyai sifat positif terhadap pekerjaannya juga menunjukan penyesuain pribadi dan sosial yang lebih baik.

Paul B. Horton dan Chester L. Hunt (1993) mengungkapkan pada keluarga di Amerika, perubahan yang paling besar adalah peningkatan jumlah "istri yang bekerja". Wanita yang telah menikah bekerja untuk menambah penghasilan keluarga. Secara historis, seorang wanita yang bekerja adalah bukti yang hidup bahwa ia tidak mempunyai suami yang mampu atau bersedia mendukung hidupnya. Alasan lain istri bekerja adalah pola hidup yang konsumtif mendesak para istri bekerja karena penghasilan hanya dari suami tidak mencukupi "standard normal" (keluarga Amerika) dalam memenuhi kebutuhannya. Selanjutnya istri bekerja mempengaruhi terhadap sesuatu yang harus dilepaskan oleh istri karena waktunya tersita oleh pekerjaan biasanya pekerjaan-pekerjaan rumah tangga dilakukan dengan bantuan pembantu rumah tangga. Rata-rata, para suami dan anak menganggap lazim pembagian tugas rumah tangga harus dilakukan oleh ibu atau istri walaupun bekerja baik langsung ataupun menggunakan jasa pembantu rumah tangga.

Berdasarkan uraian diatas bahwa banyak hal yang positif terjadi dengan istri bekerja, walaupun banyak konsekuensi yang 
harus dilaksanakan berkaitan dengan kurang maksimalnya waktu karena tersita oleh pekerjaan. Akan tetapi, pendapat diatas menunjukan bahwa pengaturan waktu, kerja sama didalam keluarga serta perlakuan yang layak bagi buruh dari pihak perusahaan, maka istri yang bekerja akan lebih baik dan positif. Akan tetapi, hal ini sering menimbulkan ketimpangan dalam melaksanakan peran ganda sebagai ibu rumah tangga dan pekerja. Sedangkan apabila tidak bekerja maka kebutuhan keluarga tidak dapat sepenuhnya terpenuhi. Kondisi ini yang banyak menyebabkan ketidakharmonisan dan kualitas menjadi rendah dalam membangun dan membina sebuah keluarga pada wanita yang bekerja.

Kebutuhan mempunyai arti sesuatu yang harus dipenuhi. Istilah "sesuatu" ini dapat berwujud keinginan, kehendak, harapan dan keadaan. Dalam hubungan dengan definisi tersebut "The American Heritage dictionary menjelaskan pengertian kebutuhan adalah "Need is condition or situation in which something necessary or desirable is required or wanted." (Morris dalam Agus Wahyudi Riana, 2007:61).

Kebutuhan-kebutuhan dasar anak meliputi Asuh, Asih dan Asuh.

\section{Kebutuhan Fisik-Biologis (ASUH):}

Meliputi kebutuhan sandang, pangan, papan seperti: nutrisi, imunisasi, kebersihan tubuh \& lingkungan, pakaian, pelayanan/pemeriksaan kesehatan dan pengobatan, olahraga, bermain dan beristirahat.

a) Nutrisi:Sejak anak di dalam rahim, ibu perlu memberikan nutrisi seimbang melalui konsumsi Makanan yang bergizi. Air Susu Ibu (ASI): nutrisi yang paling lengkap dan seimbang bagi bayi (terutama pada 6 bulan pertama atau ASI Eksklusif). Menu seimbang: protein, karbohidrat, lemak, vitamin, mineral, air

b) Imunisasi: anak perlu diberikan imunisasi dasar lengkap agar terlindung dari penyakit-penyakit yang dapat dicegah dengan imunisasi.

c) Kebersihan: meliputi kebersihan makanan, minuman, udara, pakaian, rumah, sekolah, tempat bermain dan transportasi.

d) Bermain, aktivitas fisik, tidur: anak perlu bermain, melakukan aktivitas fisik dan tidur karena hal ini bermanfaat untuk:

- merangsang hormon pertumbuhan, nafsu makan, merangsang metabolisme karbohidrat, lemak, dan protein

- merangsang pertumbuhan otot dan tulang

- merangsang perkembangan

e) e.Pelayanan Kesehatan:Anak perlu diperiksa secara teratur. Contoh pelayanan kesehatan yang teratur pada anak Balita adalah: anak ditimbang minimal 8 kali setahun, dilakukan SDIDTK minimal 2 kali setahun dan diberikan kapsul Vitamin A dosis tinggi 2 kali setahun yaitu setiap bulan Februari dan Agustus. Tujuan pemantauan yang teratur untuk:

- mendeteksi secara dini dan menanggulangi bila ada penyakit dan gangguan tumbuh-kembang

- mencegah penyakit

- memantau pertumbuhan dan perkembangan anak.

2. Kebutuhan kasih sayang dan emosi (ASIH):

Pada tahun-tahun pertama kehidupan, hubungan erat, mesra, dan selaras antara ibu/pengganti ibu dengan anak merupakan syarat mutlak untuk menjamin tumbuh kembang yang selaras baik fisik, mental, maupun psikologi. Berperannya dan kehadiran ibu/pengganti ibu sedini dan selanggeng mungkin, akan menjalin rasa aman bagi bayinya. Ini diwujudkan demgan kontak fisik (kulit/mata) dan psikis sedini mungkin, misalnya dengan menyusui bayi secepat mungkin segera setelah lahir. Kekurangan kasih sayang ibu pada tahun-tahun pertama kehidupan mempunyai dampak negative pada 
tumbuh kembang anak baik fisik, mental maupun social emosi, yang disebut "Sindrom Deprivasi Maternal". Kasih sayang dari orang tua akan menciptakan ikatan yang eratdan kepercayaan dasar.Pada tahun-tahun pertama kehidupannya (usia dini) bahkan sejak anak masih di dalam kandungan, anak mutlak memerlukan ikatan yang menciptakan rasa aman dan nyaman.

Untuk itu upayakan agar:

- anak merasa dilindungi

- memperhatikan minat, keinginan, dan pendapatnya

- memberi contoh, tidak memaksa

- membantu, mendorong/memotivasi menghargai pendapat anak

- mendidik dengan penuh kegembiraan melalui kegiatan bermain

- melakukan koreksi dengan kegembiraan dan kasih sayang (bukan ancaman/hukuman).

\section{Kebutuhan Stimulasi (ASAH)}

Untuk memperoleh perkembangan yang optimal, anak perlu 'diasah' melalui kegiatan stimulasi dini untuk mengembangkan sedini mungkin kemampuan sensorik, motorik, emosi-sosial, bicara, kognitif, kemandirian, kreativitas, kepemimpinan, moral dan spiritual.

Dasar perlunya stimulasi dini:

- milyaran sel otak dibentuk sejak anak di dalam kandungan dan belum ada hubungan antar sel otak (sinaps)

- orang tua perlu merangsang hubungan antar sel-sel otak

- bila ada rangsangan akan terbentuk hubungan-hubungan baru (sinaps)

- semakin sering di rangsang akan makin kuat hubungan antar sel-sel otak

- semakin banyak variasi maka hubungan antar se-sel otak semakin kompleks/luas
- merangsang otak kiri dan kanan secara seimbang untuk mengembangkan multipel

- inteligen dan kecerdasan yang lebih luas dan tinggi.

- stimulasi mental secara dini akan mengembangkan mentalpsikososial anak seperti: kecerdasan, budi luhur, moral, agama dan etika, kepribadian, ketrampilan berbahasa, kemandirian, kreativitas, produktifitas, dst.

Dalam pasal 47 ayat (1) dikatan bahwa anak yang belumn mencapai umur 18 (delapan belas) tahun atau belum pernah melakukan pernikahan ada dibawah kekuasaan orang tuanya selama mereka tidak dicabut kekuasaan orang tuanya. Pasal 50 ayat (1) menyatakan bahwa anak yang belum mencapai umur 18 (delapan belas) tahun dan belum pernak kawin, tidak berada di bawah kekuasaan orang tua, berada dibawah kekuasaan wali.nDari pasalpasal tersebut di atas maka dapatlah disimpulkan bahwa anak dalam UU No1 tahun 1974 adalah mereka yang belum dewasa dan sudah dewasa yaitu 16 (enam belas) tahun untuk perempuan dan 19 (sembilan belas) tahun untuk laki-laki.

\section{SIMPULAN}

Pada era globalisasi ini banyak perempuanperempuan yang memilih bekerja menjadi wanita karier, hal ini disebabkan banyaknya kebutuhan yang harus dipenuhi. Selain itu, hal ini dipengaruhi juga oleh penghasilan suami yang tidak mencukupi sehingga membuat seorang istri harus bekerja agar dapat memenuhi kebutuhan hidup. Perempuan yang bekerja memang memberikan dampak yang positif, namun disisi lain sering terjadi ketidak harmonisan di dalam keluarga. Hal ini disebabkan karena sulitnya membagi waktu antara berperan sebagai seorang wanita yang bekerja dan menjadi seorang istri sekaligus ibu 
yang bertanggung jawab dalam mengasuh, mendidik dan memenuhi kebutuhan anak.

Adanya kesulitan dalam pembagian waktu ini sehingga menyebabkan kurangnya waktu yang tersedia bersama anak, hal ini berdampak pada pemenuhan kebutuhan dasar anak. Seorang anak yang ibunya bekerja cenderung harus lebih mandiri dalam memenuhi kebutuhan dasarnya. Apabila seorang anak meningkatkan kemandiriannya, walaupun ia tidak bersama ibunya sepanjang hari maka kebutuhan dasarnya akan terpenuhi. Namun hal ini tidak menutup kemungkinan bahwa anak yang ibunya tidak bekerja pun belum tentu kebutuhan dasarnya dapat terpenuhi. Hal ini bergantung pada bagaimana pola asuh yang di terapkan oleh orang tua terutama ibu dan bagaimana kemandirian dari seorang anak.

\section{Daftar pustaka}

Hurlock Elizabeth.Psikologi perkembangan, Erlangga, 1980

Santrock John.Perkembangan anak,Erlangga, 2008

Rumini Sri dan Siti Sundari. Perkembangan anak dan remaja, Rineka cipta, 2010

www.zona-psikologi.com (diunduh pada 25 maret 2015) 